\title{
The Education-to-Work Transition of Young Rural-Urban Migrants in Kathmandu, Nepal
}

\author{
Neha Basnet ${ }^{1}$ (D) Margaretha C. Timmerman ${ }^{1} \cdot$ Josje van der Linden ${ }^{1}$
}

Received: 24 March 2020 / Revised: 8 November 2020 / Accepted: 10 November 2020 /

Published online: 23 November 2020

(C) The Author(s) 2020

\begin{abstract}
This article examines the experiences of youth transitioning from education to work, within the specific context of rural-urban migration in Nepal. This context is chosen as, compared to developed countries, experiences in developing ones have remained under-researched in the transition studies literature. The study is informed by a biographical research approach, using qualitative longitudinal life (hi)story methods, with a view to revealing local transition patterns and the life events influencing these. The study identifies four different patterns reflecting the education-to-work transitions of young rural-urban migrants in Nepal. These patterns encompass different pathways involving education, migration, work, and mandatory waiting periods. The analysis of these transition patterns highlights how migration for education and work from rural to urban settings, taken together with mandatory waiting periods, exerts key influence on the overall life trajectories of young rural-urban migrants in Nepal's capital.
\end{abstract}

Keywords Education-to-work transition · Rural-urban migration - Life events · Qualitative longitudinal research $\cdot$ Biographical approach $\cdot$ Nepal

\section{Introduction}

Several studies have noted that the transition period from youth to adulthood has been extended and the routes young people are taking have become unpredictable (see, for

Neha Basnet

n.b.basnet@rug.nl

Margaretha C. Timmerman

m.c.timmerman@rug.nl

Josje van der Linden

c.j.van.der.linden@rug.nl

1 University of Groningen, Groningen, The Netherlands 
example, Allen 2016; Gale and Parker 2014; Cuervo and Wyn 2014). Dwyer and Wyn (2004) argue that patterns of education-to-work transition among youth have changed from linear to non-linear routes. Thus, we have to be cautious to think that all young people follow the same route. Education-to-work transition patterns differ depending on the context (Chen 2018; Juárez and Gayet 2014; Karki 2014). In order to address this diversity, transition studies have taken a biographical approach (Moen et al. 1994; Thomson et al. 2002; Neale 2015). This approach contends that young people's biographies are structured by 'critical moments' (Thomson et al. 2002). 'Critical moments' are understood as events marked by, for example, engagement in paid work, education, or moving to a new house, significantly impacting on individual life and identity (Giddens 1991). To understand the significance in individual life trajectories, these 'critical moments' are the focus in transition studies. This paper, however, moves beyond the focus on 'critical moments' engaging also with temporalities in biographies. Honwana's (2014) work on waithood as a process of active engagement and reflection and Jeffery's (2010) work on waiting periods as life temporalities are used to understand the importance of waiting. Both authors show how experiences of waiting form a prominent life event in youth education-to-work transition. Honwana (2014) uses the concept of waithood to understand the prolonged period of suspension in young people's life in Ghana when their social adulthood is either delayed or denied. She argues that temporalities such as waiting do not form a situation of youth being stuck. Rather, waiting serves as an active practice of engagement, reflection, and 'becoming' in everyday lives of young people. Jeffery (2010) describes moments of waiting as moments that can both act as a vacuum space without any action and as an opportunity to escape the life boredom often arising with it. This article combines critical moments and temporalities such as waiting periods to analyse the education-to-work transition studies of young people in Nepal.

This study is part of a larger research exploring the education-to-work transition of rural-urban migrant young people working at call centres in Nepal. As their experiences reveal realities that do not match youth education-to-work transition as a linear pathway to adulthood, these young rural-urban migrants working at call centres were chosen to explore the education-to-work transition in Nepal. Drawing on qualitative longitudinal data obtained from twenty-four rural-urban migrants working at call centres, this study examines the different patterns of education-to-work transition among young rural-urban migrants in Nepal. The biographical approach allowed to understand the perspectives and nuanced views of individuals on their lives.

\section{Education-to-Work Transitions in South Asia and Nepal}

Various studies show that also in the South Asian context young people's trajectories are prolonged and have become uncertain (Chen 2018; Juárez and Gayet 2014; Jeffery 2010). The educational context in South Asia encourages young people to forge for educational credentials to provide them with the possibility of a prestigious job and a standardised biography (Naafs and Skelton 2018; Sugden and Punch 2016). The ability to work after education and to form a family is celebrated as an important marker of adulthood. However, the Nepalese educational system has been unable to impart the required skills for a successful integration into the labour market (Brown et al. 2017). Many young people are observed staying longer in education and entering later in the 
labour market (Chen, 2018). Critical life events such as marriage and parenting are postponed (Sugden and Punch 2016; Juárez and Gayet 2014). Some scholars even have questioned whether young people in the South Asian context will ever attain standard biographies at all (Jeffery 2010). The rise of educated youth unemployment delaying the passage to social adulthood (Jeffery and Young 2012) has rendered young people vulnerable to structural conditions that generate poverty and social inequality (Chen 2018; Juárez and Gayet 2014). Many people in South Asia perceive that a successful transition to adulthood requires migration for education and work within the country or abroad (Brown et al. 2017). But, for these young rural migrants, the chances of successfully obtaining a job vary by class, gender, and other social divisions. Limited opportunities and access to resources in most of the rural settings have worked as push factors for migration. As migration from the rural settings modifies and exacerbates young peoples' trajectories, the need for a better understanding of education-to-work transitions of the rural-urban migrants rises.

\section{Rural-Urban Migration for Education and Work in Nepal}

In Nepal, where the rural-urban migration figure stood at 2.6 million in 2011 (KC 2003), migration is seen as the gateway allowing individuals access to resources and opportunities that cannot be found in their own communities. Rural youth who aspire education beyond secondary school are compelled to migrate to the city (Luintel 2015). The capital Kathmandu - home to 980,000 inhabitants (Central Bureau of Statistics 2020) - has the highest number of migrants (Luintel 2015). A World Bank (2016) report revealed that young people (aged 15-40) make up 40\% of the total Nepali population and a few years earlier, in 2011, the Census Bureau of Statistics recorded Kathmandu as having the highest youth population nationwide-some 52.9\% (KC 2003). Scholars have focused on young people's struggle for educational access and on mobility linked to improving their standard of living and quality of life (Brown et al. 2017; Thomson and Taylor 2005; Timalsina 2011). This perspective assumes migration to be a shortterm strategy adopted to stay 'on track' in the conventional education-to-work transition route (Robertson et al. 2018). But, as argued by Crivello (2011), migration also influences the transition patterns of an individual from one life stage to another. In this sense, it plays a crucial role in the life of individual people, transforms their pathways, and has a life-long impact, particularly in a developing country like Nepal. For rural youth, urban migration can be an important factor shaping life trajectories. Therefore, it has become important to understand how such migration unfolds in the education-towork transition process within a developing-country context.

The macroeconomic situation in Nepal has shifted following the demographic changes occurring with globalisation, Service-sector and sales jobs make up the second- and third-highest forms of employment respectively after agriculture. Shrestha and Sharma (2013) note that students either enrolled in college or with posthigh-school degrees are working in 6000 business process outsourcing companies operating formally or informally in Kathmandu. Many of them work in call centres (Pradhan 2017). Patel (2010) describes this as work that is done 'over the wire', with sufficient telecom and internet facilities, which provides voice-based or web-based information and support to clients in the country or abroad through English-speaking personnel. According to Patel (2010), young people working in Indian call centres are 
middle-class graduates. In Nepal, call centre workers have at least a minimum education and a fair level of English (Pradhan 2017). As call centres are a relatively new phenomenon in Nepal, there is no relation between working in such a centre and a specific class position. Meeting the basic requirements is enough to enter this job, which seems to play a role in the transition from education to work for educated youth from different backgrounds. That is why call centres were chosen as the place to study these relatively new trajectories.

So far, youth studies in Nepal have focused predominantly on educational trajectories, national labour policies, and on the nexus between poverty and education (see, for example, Naafs and Skelton 2018); biographical narratives reflecting youth educationto-work transition patterns have not been studied yet. This article claims to contribute to filling this caveat with call centres in Kathmandu, Nepal's capital, as the research site. The research question to be answered is which education-to-work transition patterns exist among the young rural-urban migrants working in Nepal?

\section{Research Context, Methods, and Ethics}

\section{Research Context}

The research underpinning this article was conducted at various call centres in Kathmandu. Nepal's capital city is viewed as an interesting and vital research site because of the rapid social, economic, political, and cultural changes that it has undergone over the last few decades. In addition, the youth population there is made up of migrants from across the country who came to the capital in search of work and/or for higher education (Luintel 2015). Research participants were thus from diverse backgrounds, and their varying motivations and experiences allow for a rich exploration of transition patterns regarding access to education, resources, and the labour market, drawing on qualitative longitudinal data obtained over a 12-month period from April 2018 to March 2019 from twenty-four young people. Through snowball sampling, participants were recruited from various call centres in Kathmandu. They were selected based on their rural origin in different regions and their age between 16 and 25 years old. Research participants were selected from various call centres because the call centres work do not represent the type of work that young people aspire to have. Specific data on social class, ethnicity, or parental occupation(s) and ethnicity were not gathered, as the study was not originally designed to explore these issues. The biographical approach allowed to understand the perspectives and nuanced views of the individuals on their life trajectories.

\section{Research Methods}

Miller's (2000) qualitative longitudinal (QL) methodology was used to explore how young people navigate the transition from education to work, and the life events influencing this transition. Life-history interviews were accompanied by a life-course timeline mapping exercise (Kolar et al. 2015), to support participants to tell their stories in a more elaborated and reflective manner - as suggested by Bagnoli (2009) and Worth (2011). Using these research methods, education-to-work transition patterns were identified, categorised, named, and examined. The interviews were conducted 
in two phases. The first generated 24 in-depth interviews with 12 men and 12 women, along with timeline mapping, reflective reporting, and document analysis. The life (hi)story interviews covered the lives of the participants from birth until the time of their employment at a call centre in Kathmandu.

In the second phase, data were gathered with the same research participants after a six-month interval. The follow-up research was conducted with a reduced participant count of 21: 11 males and 10 females. The remaining three could not be traced down as their mobile phones were switched off and they did not reply to emails. In this second phase, participants' employment and educational status was documented so as to note any changes since the previous interview round. The second phase also uncovered any key issues potentially missed during the first.

Interviews were fully transcribed and evaluated. Data analysis was performed manually given that the interviews were small in number. Each one was analysed on a line-byline basis. Themes were generated using Braun and Clarke's (2006) guide to thematic analysis. As a group, participants yielded up to 34 issues in line with education-to-work transitions, ranging from family background to self-evaluation. These 34 issues were then consolidated to form thematic clusters: family, moving, education events, waiting periods, career paths, strategies for anticipated change and unanticipated change, life circumstances, and self-evaluation. To explore Nepalese education-to-work transition patterns, four thematic clusters - education, migration, jobs/employment, and waiting periods - were used. Initially, only the first three clusters were identified; in the data analysis, however, also the waiting periods frequently emerged in participants' accounts - and hence they were subsequently integrated. The waiting periods are the mandatory breaks following the two major large-scale standardised tests in the Nepali education system allowing time for the results to be processed. The first (WP1) lasts three months and is observed after the final examination at the school-leaving age, also commonly referred to as the School Leaving Certificate (SLC). The second (WP2) is a six-month break after the final examination of the 12th standard, which is commonly known as the Higher Secondary Education Board (HSEB) examination.

\section{Research Ethics}

The study aimed at elucidating the life stories of youths between the ages of 16 and 25 years old, and not merely using them as informants for data mining. Throughout the research process, ethical issues related to conducting research with young individuals as study participants were managed with care. Before engaging with the participants, informed consent was acquired both orally and through a signed consent form. With their consent, the pseudonyms they used at the call centre to protect their identity were used in this study.

\section{Results}

\section{Patterns of Education-to-Work Transition in Nepal}

Using the four selected thematic clusters, the study identified four transition patterns which are outlined and discussed below: 
1. School, work, and back to education: Ten research participants (five females and five males) working at different call centres during the first interview period were waiting for their secondary education results and planned to continue higher education. These young people had completed Nepal's ten years of compulsory education (in this time frame, playgroups are excluded) when they were between the ages of 14 and 16 years old. They had taken computer-training ${ }^{1}$ classes or were 'relaxing' during the first three months of the waiting period following the SLC examination (WP1). Two had gone on to secondary education for two years in their place of origin or to medium-sized cities within their respective regions. Only one female took a two-year diploma course in a specialised field. All of them were aiming to pursue university education either in Nepal or abroad. Working in a call centre was their first work experience during the second waiting period after the HSEB examination (WP2). One female participant revealed that she was using her time working at the call centre as cover while re-taking the subjects she had failed in the HSEB examination. All participants adhering to this pattern worked at a call centre for only a short time. By the second interview phase, all were enrolled fulltime in higher education.

2. Combining education and work: Six research participants (four females and two males) were found to be combining study and work. Working multiple positions concurrently and changing jobs several times within a year was a prevalent characteristic among all the young people identified in this pattern. Call centre jobs were not on their lists of desired ones. However, financial commitments to their family and a desire for higher education compelled them to work there. These young people were waiting to complete their university education, and navigated their way to jobs that matched with their educational backgrounds. Those who fell under this pattern took any work opportunity that came their way. During the second interview phase, participants were still found to be combining work at the call centre and study.

3. Short educational route and job: Five research participants (one female and four males) who had no interest in their studies or had lost interest in them fell within this pattern. Their lack of interest in education was attributed to various external factors during their schooling, such as drug addiction, focus on sports, or family problems. The perceived value of higher education was much less in their case compared to the fourth pattern, due to non-academic interests- which led them to discontinue their education after completing secondary school. The four young men had been employed in several menial jobs while still in school or afterwards. The call centre job was the first work experience for the female. Of the four young men, one gave guitar lessons to young children in his community and another uploaded mobile games for young people in exchange for money. For the remaining two, working at the call centre was their first work experience. At the time of the second interview, of the four males, one had already migrated abroad for work, two were in the process of applying for jobs abroad, and the other two were still working at a call centre.

\footnotetext{
${ }^{1}$ Due to the low penetration of computers into schools in Nepal, high-school graduates - especially those from rural ones - will not have been exposed to computers. Hence, it has become almost a rite of passage to enrol in computer-training classes after high school so as to acquire basic computer skills.
} 
4. Educated and underemployed: Three research participants (two males and one female) followed this pattern. They had migrated to Kathmandu to find employment after completing their higher education. Both male participants migrated after completing their master's degree, while the female participant migrated after completing her bachelor's degree. They were almost 25 years old at the time of interview, and had some prior work experience: tutoring children, working at their parents' tailoring shop, and engaging in door-to-door sales. These three young people had migrated to different locations within Nepal or abroad for educational reasons at an early age. Both of the males had worked as teachers in rural schools. They were eligible to find work in their respective fields. Still, according to them, their aspirations were blocked by not having so-called afno manchhe ('my people') connections $^{2}$ in the labour market who could find them suitable jobs, for example in banks or government sector. These young people were unemployed for periods of several months to a year after their education. Therefore, they had to take work at a call centre despite being higher qualified.

The analysis of the interview data highlights constellations of life events that can be widely understood to have influenced the biographies of these young people, albeit in different ways, combinations, and with varying intensities. Whereas, the most common such event was migration, another influential event was found in the waiting periods.

\section{Migration for Education and Work}

This section now turns to rural-urban migration to Kathmandu. While voicing their motivation for this, participants mentioned two key factors: education and work. They had all come to the capital to either pursue quality education that was unavailable in their home regions or with the hope of securing better employment opportunities. This section shows how migration influenced each of the respective transition patterns.

School, work, and back to education: For the participants who fell within this group, migration to Kathmandu occurred at a much earlier stage compared to the other participants. A few of them migrated there at a young age with their parents or relatives as a result of a decision taken by the family; the others migrated after completing secondary education. Some participants shared the contrasting views of their rural homes and how these were different to outlooks in the city, demonstrating perceptions of modernity and progress:

like in Solu, I never saw cars and here I saw cars [giggles] [...] then there [in Solu] we only had sheep, goats, big stones near the river [laughs] [...] it was a little surprising for me (Shreepa, 19)

Often, young people tend to long for urban culture and lifestyle (Thomson and Taylor 2005), and this desire has also been seen to encourage or facilitate migration and mobility among them in different contexts (Holdsworth 2009).

\footnotetext{
${ }^{2}$ Subedi notes that the term afno manchhe designates 'one's inner circle of associates - it means “one's own people" and refers to those who can be approached whenever need arises' (2014: 60).
} 
After my chance-exam [re-examination], I returned from Solu to Kathmandu, since that time I started to think that I should do something now

My friend saw the call centre job in one of the local newspapers [...] there was an advertisement about a call centre job guaranteed after training at Nepalese Rupees 3,500 (Shreepa, 19)

For young people belonging to this pattern, establishing financial independence from their parents and completing secondary education made it easier for them to be an 'adult'. Just like the other participants, Shreepa felt that migrating to the city provided her with enhanced life opportunities (Robertson et al. 2018). By the second round of interviews, young people from this group were found to be either enrolled to study for their bachelor's degree or to have migrated abroad for further studies.

Combining education and work: In this pattern, participants were found to have migrated to Kathmandu after their compulsory education. Some did so with their families, while others came alone.

I was just doing some small work in the shoe factory while I was in high school $[\ldots]$ then there was someone my father knew and he was from our village [...] something like an uncle $[. .$.$] and he was also sort of in politics [...] so we spoke$ with him and he asked me to come to Kathmandu for a job [...] I came here and started working along with my bachelor's (Ray, 25)

Ray is a good example of the participants identified in this pattern. His story confirms that rural-urban migration did not push these individuals into the workforce nor did it facilitate their transition from education to work. These participants were seeking to combine work and study even before they moved to the city. However, opportunities to combine the two became available to Ray after migrating. For the research participants adhering to this pattern, combining study with work was a consequence of their financial obligations regarding the family (Chiswick and Miller 2012; Cyranoski et al. 2011).

like our family financial situation was not that good [...] my father lost his job as musician in a school [...] he was unemployed [...] being the eldest among the siblings it was my responsibility to support my parents financially (Rhythm, 25)

Short educational route and job: The research participants in this pattern migrated to Kathmandu with their parents or relatives and entered the job market right after completing their compulsory education, for diverse reasons, including a lack of interest in further study.

I did not go to school. Because I hate school [...] I don't like crowds. I don't like a class with 40 students in it, I hate it [...] at my friend's [...] so it's like there was a ground [...] at first I did not know how to play well [football]. My friends taught me how to play [...] so then it became a habit to play with them. How can I put it $[\ldots]$ it was like an addiction. (Keith, 25)

This reveals that for some participants experiences related to education were unpleasant, and not conducive to the needs of the individual. Keith dropped in and out of 
school several times, demonstrating a lack of desire to remain part of the school environment. The other four participants also seemed academically disinclined, having failed in multiple subjects before finally completing their SLC.

As soon I entered Kathmandu, I went directly to stay with a brother from our village [...]. After that a friend of mine offered me a job, and I said ok. (Natasha,

25)

Educated and underemployed: The three research participants identified in this pattern had migrated to Kathmandu alone after completing their higher education. They had exhausted every avenue for seeking employment in their respective educational fields, without success.

I was rejected [...] I started to think it was probably my fault. My teacher, who was also one of my favourite teachers during my bachelor's studies, told me and my parents "it is really sad that he did not get selected in the interview but then there are other jobs he can also do" [...] without thinking twice I came to Kathmandu for a job. I stayed with a brother ${ }^{3}$ from our village in Bhaktapur and that's how I ended up here [at the call centre]. (John, 24)

This quote shows that such participants had few structured pathways, and fewer options than those entering higher education after some time working. The post-secondary education period for the group in this pattern was a difficult and chaotic one, with either complex choices or a lack of opportunities and little discernible institutional support (and in their case, a lack of afno manchhe connections). Eventually, the young people in this group were able to find work after they moved to Kathmandu - but they had to accept positions that did not match their educational background or aspirations. For the young people in this pattern, migration served to get a job which satisfied their immediate needs but did not fulfil their wishes for a better future (Thomson and Taylor 2005).

Reviewing these responses, it is clear that migration played an important role in young people's pathways - albeit occurring at different life stages for them. Some migrated to Kathmandu right after secondary school, whereas some did so after completing higher education. Rural-urban migration and its influence varied across patterns. Regarding 1 and 4, this influence was found to be rooted in migration to the city - being a signifier of upward social mobility (Crivello 2011; Valentin 2011). For pattern 2, rural-urban migration facilitated better job options. For pattern 3, migration led to earlier work opportunities that came with shorter education routes. Furthermore, these responses provide glimpses into the social class positioning of the young, that is, their ability to secure resources to migrate to the city and access to education and the labour market.

\section{Waiting as a Life Event}

The nature of the Nepalese education system creates, as noted earlier, two distinct waiting periods (WP1 and WP2) in the education-to-work transition process. WP1 and

\footnotetext{
${ }^{3}$ In Nepal there is a practice of calling all your cousins, even many times removed, 'brother'. This also applies to anyone who is not directly related by birth but who is from the same locality/village.
} 
WP2 emerged as important life events among the participants in this study, apart from rural-urban migration for reasons of education and work. In this section, it is shown how WP1 and WP2 have influenced the transition patterns of young people in Nepal.

School, work, and back to education: To a large extent, the young people identified in this pattern showed that they had to do something during WP1 and WP2 to keep themselves busy and make use of their time.

During WP1, most of the participants identified of this group took computer-training courses with the hope that this would help them find a job, or because everyone else around them was taking a course while waiting for their exam results. WP2 came about when the participants were seeking to enter the job market in some form or other.

So after the HSEB examination, I went to Pokhara to stay with my uncle. I decided to join my uncle's business [his uncle provides services such as solar panels and solar water] until the results came out. I even thought of joining a bachelor's programme in Pokhara and working at the same time, but the exam results were not good so I came back to Kathmandu. (ArJay, 21)

Combining education and work: Similar as for pattern 1, these particular participants were also observed to have started working; few had migrated to the city during WP1 and WP2. Participants in this pattern were observed to be combining study and work from a young age. Both WP1 and WP2 provided them with opportunities to work fullrather than part-time (Te Riele 2004) while studying. This helped them to fulfil their family responsibilities as well as their personal goals.

One of our sisters (in the neighbourhood) got cancer and I took care of her during the three-month gap [...] then during the WP2, I joined a finance company as an administrator (Rhythm, 25)

Short educational route and job: Unlike the other patterns, participants in this group discontinued their studies and entered directly into the job market. In this pattern, the participants entered into the job market at a young age and this facilitated their migration to the city or even abroad.

I got failed in my class 12 th final examination. I had to wait one year to re-appear for the exam. I gave the re-examination but again got failed. So I was like [...] I did not try again and started looking for jobs. I was providing guitar lessons to children from the British school [...]. I was working only three days a week and I needed a second job. My friends were working at a call centre and I too joined it. It was a night job and the other one was a day job so I thought I could manage, but now I am apply for a work visa in Japan. Let's see. (Jimmy, 25)

I was working at the souvenir shop of my uncle [...] half day of class and then work until late hours [...]. Before the SLC, I took a break to prepare for the exams [...] I left it after SLC [...] I went to Malaysia for work (Keith, 25)

Educated and underemployed: The research participants in this pattern were either taking skills-development or computer-training courses, or just relaxing during WP1. During WP2, participants took part-time jobs or went abroad for higher studies. 
I always wanted to study aviation [...] after WP2, since there was no aviation college in Nepal but there was an institute called APTECH [...] and they linked me to the APTECH in Delhi [...]. Then I travelled to Delhi. (Peter Brown, 23)

This shows that in this pattern both WP1 and WP2, WP2 even more than WP1, facilitated the education-to-work transition process of participants, by enabling them to enter the labour market.

Comparing the two waiting periods, participants exhibit a lot of similarities during WP1 - wherein they were all enrolling into courses that might help them enhance their skill set, with the exception of those adhering to pattern 2 . For three participants in the latter, WP1 was the period when they entered the job market despite having a limited education. During WP2, all participants across all four patterns were jobholders. For many, WP2 facilitated their rural-urban migration. Most clearly, this can be seen from the life stories identified as belonging to pattern 1, specifically from the accounts of Shreepa and ArJay. Their experiences in the waiting periods combined with rural-urban migration formed key life-events enabling them to enter into the labour market and facilitated their respective education-to-work transition processes. In all four patterns, WP1 and WP2 in combination with rural-urban migration acted as a 'seed-bed' (Jeffrey and Young 2012: 658) facilitating the transition from education to work, enabling these young people to gain skills, to enter into the labour market, and to become financially independent.

\section{Discussion}

Using a biographical approach, the education-to-work transition patterns of young, rural-urban migrants have been examined. Four transition patterns could be identified from the interviews conducted with call centre workers: school, work, and back to education; combining education and work; short educational route and job; and educated and underemployed. Although these patterns differ, life events that influence the education-to-work life trajectories, in all four of the patterns, are identifiable. Migration to the city and the two compulsory waiting periods have considerable impact on these patterns, and although these life events demonstrate the vulnerabilities that young people face they also draw attention to the positive impacts that they can have on their education-to-work transitions.

At first sight, it appears that migration is a cultural signifier of upward social mobility, just like previous research highlighted that migration is used as a tool to improve the standard of living and quality of life (Brown et al. 2017). Still, even after having migrated, the uneven distribution of the resources shapes the trajectories of young people reinforcing already existing social divisions. For few participants, especially those in pattern 1, migration to Kathmandu was an investment made by their family to improve their future perspectives; for others, especially those in pattern 4, it was to solve their immediate livelihood issues. This suggests a class dynamic to the decisions made in relation to migration informing the experiences and nuances of young people trajectories (Thomson and Taylor 2005) and their successful integration in the labour market.

Even though the young people in this study were found to migrate for education and work to Kathmandu, migration to the city does not fully capture their experiences. The 
two waiting periods WP1 and WP2 were found to be of major relevance in the participants' accounts largely determining the transition patterns. The majority of research participants across all four were observed to enter into a job during both the waiting periods, either as part-time work, as found in pattern 2, or as full-time work, as found among those adhering to patterns 3 and 4. For those in pattern 1 and others who worked in a call centre during WP2, gaining work experience was only possible because of the waiting periods. WP1 and WP2 offered the research participants with rural-urban background an opportunity to acquire skills, migrate to Kathmandu, and gain work experience. But, it also prompted giving up school altogether in few, probably limiting them to low-paid jobs and social immobility in the future. This indicates call centres were a fallback during the waiting phases among young research participants in this study used by those in need. The accounts of the participants suggest that active practices of taking up a work at the call centre or skills development training during the waiting periods reflect their class positioning in terms of financial resources, ambitions, and work connections.

Similar findings such as waiting periods were found in the narratives of young people in other developing contexts in previous studies (Jeffrey 2010; Honwana 2014) where young people had a sense of no control over the situations they were in and just waited for something to happen in their life. Those young people were engaging themselves in activities, to fill the time lost. Thus, waiting can be understood both as a disadvantage and as an advantage allowing for exploration on the education-to-work pathway. WP1 and WP2 that form part of the Nepalese education system enabled transition of these rural-urban migrants, but also created a structure full of risks and uncertainties, which seem to be partly related to class positions. The young people in this study used the time to construct better futures for themselves and for their families. The possibility to follow up with the participants in a second round of interviews deepened the insight in the role of the waiting periods, since they captured their experiences in multiple temporal and socio-political contexts - something which would not have been possible with a single data-collection process (Worth 2011).

\section{Conclusion}

This article discussed the education-to-work transition patterns that exist for ruralurban migrant youth in Nepal drawing on longitudinal research with youth in call centres. The patterns identified range from 'school, work and back to education', 'combining education and work', 'short educational route and job', to 'educated and underemployed'. As seems clear from the literature (Brown et al. 2017; Thomson and Taylor 2005; Timalsina 2011), migration modifies and exacerbates young peoples' trajectories. Analysing biographical narratives of rural-urban migrants another factor impacting on the trajectories was found in the waiting periods that form part of the Nepalese educational system. The structural challenges created by these periods often signify feelings of loss or a passive state (Jeffrey 2010), but this study shows that they can also precipitate the education-to-work transition. This shows how the waiting periods allow time for engagement and reflection, as well as 'becoming' in the words of Honwana (2014:35). To understand the lived experiences of young people's education-to-work transition patterns beyond those of the participants in this research, 
future research should be mindful of these life temporalities in Nepal and also in other contexts.

Funding This study was funded by Netherlands Fellowship Programmes (grant number CF 13175).

Data Availability The codes were generated manually. Data and codes will be made available upon request.

\section{Compliance with Ethical Standards}

Conflict of Interest The authors declare that there is no conflict of interest.

Ethical Approval The study was performed in line with the principles of the Declaration of Helsinki. Approval was granted by the Ethics committee of University of Groningen (RUG).

Consent to Participate The study used standard consent form with details of the project and it purpose. Consent forms were sent to the participants prior to the interview.

Consent for Publication Approval for the publication was taken from the participants in the consent form.

Open Access This article is licensed under a Creative Commons Attribution 4.0 International License, which permits use, sharing, adaptation, distribution and reproduction in any medium or format, as long as you give appropriate credit to the original author(s) and the source, provide a link to the Creative Commons licence, and indicate if changes were made. The images or other third party material in this article are included in the article's Creative Commons licence, unless indicated otherwise in a credit line to the material. If material is not included in the article's Creative Commons licence and your intended use is not permitted by statutory regulation or exceeds the permitted use, you will need to obtain permission directly from the copyright holder. To view a copy of this licence, visit http://creativecommons.org/licenses/by/4.0/.

\section{References}

Allen K (2016) Top girls navigating austere times: interrogating youth transitions since the 'crisis'. J Youth Stud 19(6):805-820

Bagnoli A (2009) Beyond the standard interview: the use of graphic elicitation and arts-based methods. Qual Res 9(5):547-570

Braun V, Clarke V (2006) Using thematic analysis in psychology. Qual Res Psychol 3(2):77-101

Brown T, Scrase TJ, Ganguly-Scrase R (2017) Globalised dreams, local constraints: migration and youth aspirations in an Indian regional town. Child Geogr 15(5):531-544

Central Bureau of Statistics (2020). National data. https:/www.npc.gov.np/en/page/99/department/central_ bureau_of_statistics_cbs_. Accessed 18 Oct 2020

Chen S (2018) Education and transition to work: evidence from Vietnam, Cambodia and Nepal. Int J Educ Dev 61:92-105

Chiswick BR, Miller PW (2012) Negative and positive assimilation, skill transferability, and linguistic distance. J Hum Cap 6(1):35-55

Crivello G (2011) 'Becoming somebody': youth transitions through education and migration in Peru. J Youth Stud 14(4):395-411

Cuervo H, Wyn J (2014) Reflections on the use of spatial and relational metaphors in youth studies. J Youth Stud 17(7):901-915

Cyranoski, D, Gilbert, N, Ledford, H (2011) Education: the PhD factory. Nature 472:276-279.

Dwyer P, Wyn J (2004) Youth, education and risk: facing the future. Routledge, NewYork

Gale T, Parker S (2014) Navigating change: a typology of student transition in higher education. Stud High Educ 39(5):734-753 
Giddens A (1991) Modernity and self-identity: self and society in the late modern age. Stanford University Press

Holdsworth C (2009) 'Going away to university': mobility, modernity, and independence of English higher education students. Environ Plan A 41(8):1849-1864

Honwana A (2014) 'Waithood': youth transitions and social change. In: Foeken D, Dietz T, de Haan L, Johnson L (eds) Development and equity: an interdisciplinary exploration by ten scholars from Africa, Asia and Latin America. Leiden, Brill, pp 28-40

Jeffrey C (2010) Timepass: youth, class, and time among unemployed young men in India. Am Ethnol 37(3): 465-481

Jeffrey C, Young S (2012) Waiting for change: youth, caste and politics in India. Econ Soc 41(4):638-661

Juárez F, Gayet C (2014) Transitions to adulthood in developing countries. Annu Rev Sociol 40:521-538

Karki S (2014) Education and employment: transitional experiences in Nepal. PhD Dissertations. Oxford University Press

KC BK (2003) Internal migration in Nepal. Population monograph of Nepal. Central Bureau of Statistics, Kathmandu, pp 121-165

Kolar K, Ahmad F, Chan L et al (2015) Timeline mapping in qualitative interviews: a study of resilience with marginalized groups. Int J Qual Methods 14(3):13-32

Luintel YR (2015) Livelihood change and household strategies: social displacement of the upper class in Dhading. Dhaulagiri J Sociol Anthropol 9:26-52

Miller R (2000) Researching life stories and family histories. Sage, London

Moen P, Robison J, Fields V (1994) Women's work and caregiving roles: a life course approach. J Gerontol 49(4):176-186

Naafs S, Skelton T (2018) Youthful futures? Aspirations, education and employment in Asia. Child Geogr 16(1):1-14

Neale B (2015) Time and the life-course: perspectives from qualitative longitudinal research. Researching the life-course: Critical reflections from the social sciences. 25-42

Patel, R (2010) Working the night shift: women in India's call center industry. Stanford University Press.

Pradhan S (2017) Analysis of impact sourcing by infusing social innovation in outsourcing for Nepal. In: Choudrie J, Islam M, Wahid F, Bass J, Priyatma J (eds) International Conference on Social Implications of Computers in Developing Countries. Springer, Cham, pp 829-834

Robertson S, Harris A, Baldassar L (2018) Mobile transitions: a conceptual framework for researching a generation on the move. J Youth Stud 21(2):203-217

Shrestha N, Sharma P (2013) Problems and prospects of business process outsourcing in Nepal. Available online at: http://sawtee.org/publications/Briefing-Paper-25.pdf. Accessed 12 March 2020

Subedi M (2014) Afno manchhe: unequal access to public resources and institutions in Nepal. Dhaulagiri J Sociol Anthropol 8:55-86

Sugden F, Punch S (2016) Changing aspirations, education, and migration: young people's declining agroecological knowledge in rural Asia. In: Ansell N, Klocker N, Skelton T (eds) Geographies of global issues: change and threat. Geographies of Children and Young People. Springer, Singapore, p 8

Te Riele K (2004) Youth transition in Australia: challenging assumptions of linearity and choice. J Youth Stud 7(3):243-257

Thomson R, Bell R, Holland J et al (2002) Critical moments: choice, chance and opportunity in young people's narratives of transition. Sociology 36(2):335-354

Thomson R, Taylor R (2005) Between cosmopolitanism and the locals: mobility as a resource in the transition to adulthood. Young 13(4):327-342

Timalsina KP (2011) An urban informal economy: livelihood opportunity to poor or challenges for urban governance, study of street vending activities of Kathmandu Metropolitan City. Int J Polit Good Gov 2(2.2):1-13

Valentin K (2011) Modernity, education and its alternatives: schooling among the urban poor in Kathmandu. Glob Soc Educ 9(1):99-113

World Bank (2016) Moving up the ladder: poverty reduction and social mobility in Nepal, Washington D.C Worth N (2011) Evaluating life maps as a versatile method for life-course geographies. Area 43(4):405-412 